\title{
Indi@logs
}

Vol 8 2021, pp 123-141, ISSN: 2339-8523

https://doi.org/10.5565/rev/indialogs.167

\section{Desynchronization in the Necrocene Age: The Case of the Maldives AND FUTURE SPECULATIONS}

ORIOL BATALLA

Independent Researcher oriolbatalla.95@gmail.com

Received: $05-10-2020$

Accepted: $31-01-2021$

\begin{abstract}
Through the theoretical framework of the Necrocene, the age of death and extinction due to capitalist accumulation, this article tries to analyze and flesh out the current sociopolitical and ecological crisis of the Maldives archipelago as a symptom of what is to come on a planetary scale. It will analyze how knots of life play part in the ecology of the Maldives as a case study. Through the close reading and scrutiny of contemporary literature in the fields of Environmental Humanities, Extinction Studies and Political Ecology, this essay aims to engage with the pressing matter of the Anthropocene, its materialities and its imaginaries. Finally, it ambitiously provides further thought on how to approach the Necrocene as a global multifocal crisis, aiming to build up on the idea of Climate X.
\end{abstract}

KEYWORDS: Anthropocene; Political Ecology; Critical Theory; Extinction Studies; Environmental Humanities; Maldives; Climate Change; Postcolonialism

RESUMEN Desincronización en la edad del necroceno: El caso de las Maldivas y futuras especulaciones

A través del marco teórico del Necroceno, la edad de la muerte y la extinción a raíz de la acumulación capitalista, este trabajo trata de analizar y reformular la actual crisis socio-política y ecológica usando como caso de estudio los efectos de tal crisis en las Maldivas como ejemplo sintomático de lo que está por venir en una escala planetaria. Este artículo intenta desgranar los nudos vitales que interactúan en la ecología de las Maldivas. A través del uso y escrutinio de literatura contemporánea en los campos de las Humanidades Ambientales, los Estudios de Extinción y la Ecología Política, este trabajo busca colaborar en los debates del Antropoceno, sus materialidades y sus imaginarios. Finalmente, este ensayo trata de proponer, de manera ambiciosa, ideas para afrontar el Necroceno como una crisis global y multifocal, tratando de construir futuras posibilidades a raíz de las ideas de Clima $X$.

Palabras Clave: Antropoceno; Ecología Política; Teoría Crítica; Estudios de Extinción; Humanidades ambientales; Maldivas; Cambio Climático; Postcolonialismo

The Maldives are disappearing underwater. The Indian Ocean archipelago formed by 1,190 islands grouped into 26 low-lying coral reef atolls and with a highest altitude point of just 2.4 meters above sea level is likely to become a submerged country by the end of the $21^{\text {st }}$ century 
(Stojanov et al, 2017; Alkhars, 2017). Apart from the danger this sea-level rise inflicts upon the archipelago, the Maldives are currently experiencing other slow-onset hazards that can have a dramatic effect on the inhabitants of the country. These hazards include coastal erosion, sea surface temperature rises, salinity intrusion, changes in the monsoon patterns, ocean acidification, decline and extinction of wildlife and coral bleaching (Stojanov et al., 2017; Slezak, 2016). These ecological disasters are affecting the local livelihoods, housing, freshwater access, food production, local fisheries and the tourism industry (Stojanov et al., 2017). In sum, they are affecting the stability of the Maldivian locals and their cultural agency as their livelihoods and heritage are likely to disappear in the face of the Sixth Extinction, experienced on the front-line. Despite the attempts of the Maldivian government to palliate these catastrophic consequences, policies have been approached in a top-down city-centered fashion which has excluded many islanders, putting the inhabitants of the archipelago at stake. Climate change is not the first reason for Maldivians to migrate as most leave the archipelago in search of better job, health and education opportunities (Kelman et al., 2019), yet both scientists and governments are currently discussing the inevitable migration of Maldivian islanders for the former over the latter. This signifies the displacement of entire communities due to the inhabitability of their land and thus becoming Climate Refugees.

The Sixth Extinction makes one consider the way in which "living beings call and respond; ethics are situated in bodies, in time, in place and necessarily, in encounter" (Rose, 2012: 6), andthis forces us to comprehend how the vectors of these different forces create processes which connect together the present TimeSpace and relationalities of our lives. The Maldives are suffering uneven, non-linear processes of death and extinction that are putting at stake their survival, both as an ecosystem and as a culture. Seen through an Environmental Humanities lens, this essay will fluctuate within the temporalities and realities of extinction in the Maldives from a theoretical perspective and portray how the archipelago is victim of the Necrocene. It aims to analyze the extinctive situation of the Maldives in terms of ecological and cultural degradation and some key policies that have been implemented by using the Necrocene, the age of death and extinction through capitalist mass-accumulation, as a heuristic. In this light, we shall contribute to the Anthropocene discussion by providing inroads to conceptualize and rethink new ontological and material alternatives to it. 
By rejecting the Anthropocene as "a reflection and reinforcement of the anthropocentric actional worldview" (Crist, 2016: 14) and as a narrative that extends the capitalist ruse of blaming humanity as a whole for the questions entangled within the Anthropocene crisis when they are, in fact, problems created by Capitalism, the Necrocene provides an alternative to grasp the uncanny reality of our epoch. The nomenclature of the Necrocene can help us become aware of the fact that every effect of the "Planetary Boundaries" (Rockström et al., 2009) ${ }^{1}$ over a specific set of agents is social, cultural, political and ecological. When connected to the crisis of the Maldives archipelago, the Necrocene provides us with a theory that can grasp the way the different knots of life and TimeSpaces are being unmade and desynchronized. Thus it helps us unify culture and ecology for analysis and, conversely, shed light upon how these two ideas are intertwined in the Necrocene. This will be done by touching upon the reality of the sea level rises, habitat degradation and shark decline and environmental policies. To conclude, this work will try to provide further thoughts on the possibilities beyond the Necrocene in a local and planetary scale.

\section{Understanding the Necrocene}

Although it is beyond the scope of this work to fully develop the Necrocene theory, to understand $i^{2}$ one first needs to grasp the Capitalocene (Moore, 2016) which is defined as an epoch dominated by the geological, political, cultural and ecological agency of capitalist massaccumulation. The Capitalocene identifies the division between Nature and Humanity in its world-ecology perspective in which Nature does not only refer to non-human ecosystems and agents, but also to members of human societies "such as peoples of colour, most women, and most people with white skin living in semicolonial regions" (Moore, 2016: 91). This is what Moore (2016) coined as the "Law of Cheap Nature". According to Moore (2016), the planetary order of world-ecology is divided in two big groupings: the entities subjugated to the Law of

\footnotetext{
${ }^{1}$ The nine Planetary Boundaries are "the global biogeochemical cycles of nitrogen, phosphorus, carbon, and water; the major physical circulation systems of the planet (the climate, stratosphere, ocean systems); biophysical features of Earth that contribute to the underlying resilience of its self-regulatory capacity (marine and terrestrial biodiversity, land systems); and two critical features associated with anthropogenic global change (aerosol loading and chemical pollution)" (Rockström et al., 2009). Crossing one or more of these boundaries will trigger catastrophic consequences on a planetary scale.

${ }^{2}$ See McBrien's “Accumulating Extinction” (2016), *Batalla's's Planetary Catastrophism (2019), Clark's Between Earth and Empire (2019) for further literature on the concept of the Necrocene.
} 
Cheap Nature, also known as Nature (exploited agents), and the ones outside of it, also known as Humanity (exploiters). This understanding of world-ecology can allow us to open up new spaces of analysis.

However, in the Sixth Extinction paradigm, the Capitalocene narrative fails to acknowledge the extinctive nature of Capitalism. Late-Capitalism is inseparable from extinction, environmental catastrophes, permanent expenditure, endless wastefulness and disruption of cycles and knots of life in which ecosystemic integrity depends on. As Bastian \& van Dooren (2017) elucidate upon:

In these and other fundamental ways, this is a period in which relationships between life and death, creation and decay, have become uncanny; no longer entailing what was once taken for granted. Toxic legacies, mass extinction, climate change: all simultaneously remake both temporal relations and possibilities for life and death. (Bastian \& van Dooren, 2017: 2)

Thus, as already mentioned in the introduction, the Necrocene theory established by Justin McBrien (2016) allows us to reframe the history of Capitalism's endless expansion and globalization "through the process of becoming extinction" (McBrien, 2016: 116). That is, the Necrocene connects Capitalism with the Sixth Extinction, the first extinction caused by a single species or, according to the Necrocene logic, by a modus vivendi.

The Necrocene, through the Law of Cheap Nature, aligns with the Marxist assumption that Capitalism has an only goal: expansive, never-ending accumulation. This concept helps us define and understand our current epoch as an age in which "Capitalism leaves in its wake the disappearance of species, languages, cultures, and peoples. It seeks the planned obsolescence of all life. Extinction lies at the heart of capitalist accumulation" (McBrien, 2016: 116). To put it differently, the only thing left in the Necrocene epoch is "a sovereign lack, an imperious death drive, a destructive nothingness, surrounded by a field of objects of consumption and domination" (Clark, 2019: 16).

Here one could argue that climate change processes have happened before the great acceleration and industrialization ${ }^{3}$, and that nature is an ever-changing ecosystem, disentangled from cultural practices. Yet, what is at stake in the Necrocene is that the changes in the Planetary

\footnotetext{
${ }^{3}$ Consider the Medieval Warm Period (900-1300 AD) and the subsequent Little Ice Age (1300 AD - 20 $0^{\text {th }}$ C.). Although the causes are not clear, they are generally attributed to changes in the solar activity and oceanic flows, and decreased volcanic activity. These two periods allowed human movement to other areas of the world such as Greenland or Hawaii (Botkin, 2012).
} 
Boundaries are caused and accelerated by accumulation processes, leading to a multispecies extinction beyond non-human beings. We are living in the end of nature, a time in which everything that once was "natural" (outside human culture) is now modified as humans have modified the atmosphere and, consequently, everything (McKibben, 1989). Therefore, all that once was outside human modification is now modified. This modification is then, according to the Necrocene, not due to human consequences but to capitalist accumulation.

Capitalism survives, accumulates and expands in a vampire-like nature, absorbing living labour and natural resources until the agents at hand are no longer profitable for Capitalism's ends. Therefore, we can see that Capitalism vacuums human and non-human agents towards the death of Capitalism itself. That is, Capitalism did not ignore the ecological crisis but, in turn, "made it the central problem of its survival" (McBrien, 2016: 119). As problematic it may seem for Capitalism, the current ecological/political/cultural turmoil has been viscously infected by Capitalism itself. Consequently, alternatives such as the Green New Deal or the techno-fixing of the crisis through Capitalist logic are nothing but a palliative effect on the Necrocene. Moreover, the injustices embedded in such logic, focusing solely on "green" without a "prismatic" perspective, will be perpetuated. That is, the Necrocene helps us move beyond "green" and understand the agency of Capitalism as a whole spectrum of inequalities and deathly dangers for human and non-human agents alike.

The Necrocene generates extinction. It absorbs and infects everything at its reach, bringing to the surface the rhizomatic organization of its necro-realities. Thus, the Necrocene and its necro-realities (necropolitics ${ }^{4}$, necroeconomics ${ }^{5}$, necro-ontologies ${ }^{6}$ ) are pivotal to both come to terms and challenge the Anthropocene nomenclature.

\footnotetext{
${ }^{4}$ Necropolitics is "the generalized instrumentalization of human existence and the material destruction of human bodies and populations" (Mbembe, 2003: 14). Mbembe exposes that through the negation of nature, humankind creates a world around itself. Thus, in this process, humankind becomes subjected in the negativity of such duality: death. Framing within it human and non-human beings alike, it dialectically recasts the subjects into Nature (exploited) and Humanity (exploiter) in the process of becoming extinction.

${ }^{5}$ Necroeconomics is as an economic system organized around the consumption of bodies through accumulation (Unzondu, 2013). These bodies become instrumentalized "matter", only used for the accumulation and generation of capital, being rejected if they cannot align with Capitalism's goals. These bodies are deprived of their inherent value besides their commodified value.

6 The rendering of agents, populations or ecosystems that must necessarily be killed. To be exposed to necropolitics/economics. Thus, necro-ontology can be understood "as a philosophical orientation that rationally organizes populations for their necessary death" (Unzondu, 2013: 327).
} 
The Holocene, an epoch in which all our ideas on politics, beauty or knowledge were created by humans and where civilizations thrived due to climate stability, is gone (Purdy, 2010). In the debate on the many Anthropocenes, the Necrocene is a bountiful nomenclature to scrutinize the geological, ecological and sociocultural power of Capitalism through the connection between processes of extinction and the capitalist logic. It opens new ways of understanding the current global crisis. Unlike other nomenclatures ${ }^{7}$, it helps us move towards world-ecology, putting death and extinction at the core of the debate and connecting them with the evident inequalities that lie at heart of current late-Capitalism.

\section{Desynchronization in the Necrocene: A Critical Approach to the Maldives Multifocal Crisis}

The Necrocene is affecting islands and coastal areas. The human cataclysm which is predicted by the end of the $21^{\text {st }}$ century resulting from sea level rises estimated to increase $18-59 \mathrm{~cm}$ above 1990 levels (Meehl et al., 2007), will radically alter our ontological and material perception of global reality. As an unseen event in human history, the subsequent calamities unfolding from such catastrophe will disvalue the prediction of future events through previous knowledge (Pilkey et al., 2016), affecting between 25 million and 1.4 billion people by 2050 (Geisler \& Currens, 2017). Although economicallyrich areas such as Miami or Amsterdam are bound to the same catastrophe, they have the resources to start

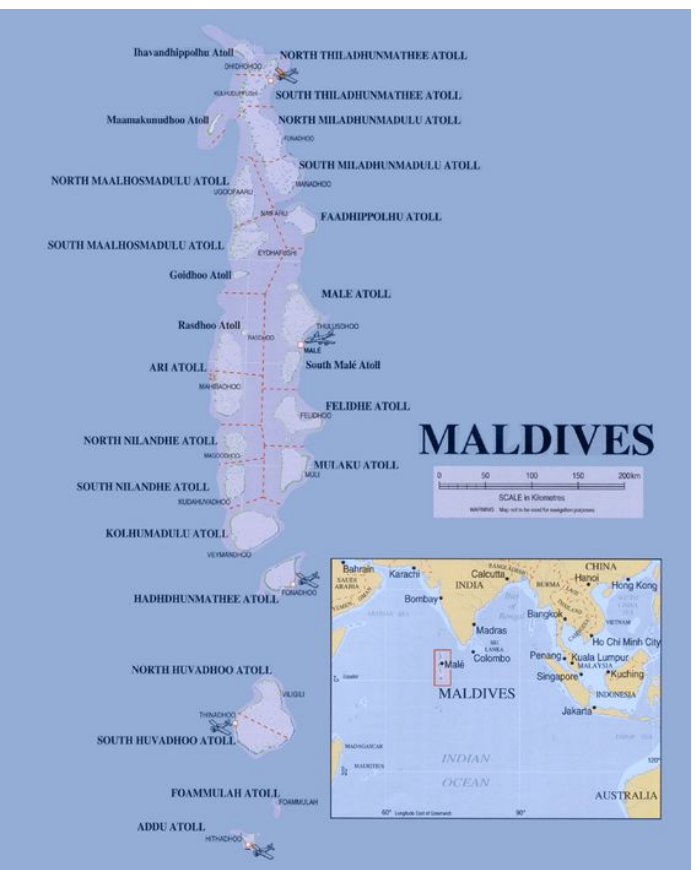

Figure 1: Map of the Maldives Archipelago. Taken from "risingsea.net" conceiving and putting into practice some short-term palliative measures to the crisis (Pilkey et al., 2016). In light of this, the peoples and cultures of low-lying islands and coastlines such as Bangladesh, Kiribati or the Marshall Islands amongst others are likely to become some of the first climate refugees due to the inhabitability of their lands and extinction of resources as a

\footnotetext{
7 Consider the "Chthulucene", "Plantationocene" (Haraway, 2015) or "Neganthropocene" (Stiegler, 2018) nomenclatures. Although very fruitful in theoretical value, none of them establishes extinction at the heart of the epoch connected with Capitalism.
} 
consequence of climate change triggered by mass-accumulation (Merone \& Tait, 2018; Pilkey et al., 2016; Farbotko \& Lazrus, 2012). In other words, "those that contribute the least to the human causes of sea-level rise will be hurt the most" (Pilkey et al., 2016: 3).

Trapped in this paradigm, the Maldives are at stake. However, to understand the crisis of the archipelago it is crucial to comprehend that the human perception of the Necrocene in modern civilization has an internal confusion about time. The perception of ecology through human rationale perceives the Earth as a system that functions in another dimensional timescale as an opposition to post-industrial neoliberal high-speed modus vivendi, a timescale that is more stable and solid where capitalist logic can run at its will. This has led humankind to think that "the changes that do occur within nature are neither significant nor relevant" (Bastian, 2009). With factors such as humidity, gravitational and electromagnetic effects, together with immortal agents such as microplastics or the unevenness of Planetary Boundaries, clocks and human rationality become unreliable to understand the processes of the Necrocene. Therefore, humans have failed to approach the agency of the Earth due to their linear, anthropocentric perception of their surroundings, ignoring most non-human agents as part of the multispecies knot of life. The treatment of ecological ecosystems as a stable background where Capitalism can perform freely is culturally problematic as it claims that the changes and modification of such ecosystems are not relevant to be scrutinized or taken care of. Thus, recognizing the world-ecology as a group of interconnected agents is realizing that an anthropocentric/capitalocentric understanding of conventional temporal models is not useful to come to terms with the Necrocene crisis.

The modification of time by the logic of 24/7 Capitalism has disrupted the temporalities of the world-ecology, modifying the shifts of both labor and ecosystems as the Necrocene has viscously infected and extinguished the natural circadian rhythms through its deathly logic. In this light, to come to terms with the Earth as an entity is to move away from Cartesian, Spinozian and Leibnizian human rationality and understanding of the physical through clocks and mathematical time towards an ecological rationality "which scrutinizes the match or fit between an agent's choices, actions and effects and that agent's overall desires, interests and objectives as they require certain ecological conditions for their fulfillment" (Plumwood, 2002: 68). Consequently, ecology needs to question the subjectivity and capitalist formations, becoming an epistemological system grounded on a comprehension of nonlinear, uneven systems ruled by 
feedback loops and nonlinear causality beyond environmentalism (Guattari, 987). This approach could help us rethink time, ecology and the current global crisis of the Necrocene from a nonanthropocentric and much more accurate world-ecology. In such ecological rationality, the Necrocene presents itself through this logic as a sum of "foldings and pleatings, about simultaneous and contradictory temporalities, about the breakdown and (re) formation of new multitemporal relations" (Bastian \& van Dooren, 2017: 7). Here, life and death are jeopardized in the midst of a tumultuous intertwining of TimeSpaces, a dark ecognosis which is overwhelmingly massive (Morton, 2016).

As aforementioned, the Maldives are one of the most affected areas by the Necrocene and its deathly logic in the world. Due to the ecocidal multifocal catastrophe that the Necrocene entails, the TimeSpaces of the Maldives islanders and of their ecological surroundings have been shaken to the core. The knots of life that have united islanders and their ecosystem are being frayed due to Necrocenic climate change. The speed in the rise of sea level and sea surface temperature during the last 30 years (Nurse et al., 2014) has caused, directly or indirectly, a desynchronization of the centuries-old knots of life that were bonded out of the mutual existence of different agents. With the surpassing of the Planetary Boundaries, the consequences are bound to be dramatic for the archipelago's topographical low-lying atolls and its people. Time here is being unmade as something that makes no sense unless perceived from a beyond-human analytical gaze. Thus, the modification of the natural TimeSpaces of the sea is unmaking the knots of life that unified the ocean with the human and non-human ecosystems for millenniums, with a consequent overlapping and disconnection of ecosystems as a whole ${ }^{8}$.

In other words, the synchronized TimeSpaces between entities such as the ocean and the Arctic ice-sheets and living ecosystems in the Maldives, perfected throughout generations, are starting to unfold in a way that time and space, knots of life and synchronization start to make no sense. As Tomba (2009) postulated, Capitalism triumphed due to its encounter with different TimeSpaces as processes of exploitation and production require "the synchronization through extra-economic violence in order to produce differentials of surplus-values, and to be synchronized with the world-rhythm of socially-necessary labour" (Tomba, 2009: 56). However, the Maldivians have managed to challenge the TimeSpaces of the Necrocene through

\footnotetext{
${ }^{8}$ For examples on desynchronization, consider Bastian's (2017) "Encountering Leatherbacks in Multispecies Time Knots".
} 
conservation. With reef sharks functionally extinct in most of the reefs of the world and unable to perform their role in an ecosystem due to its decline of population (Tasoff, 2020), the 2010 shark fishing ban in the Maldives has proven to be very effective in protecting the different species that inhabit the waters of the archipelago. This allowed the Maldives to sustain some of its marine ecosystems and the wealth they provide to the archipelago in the short-run.

Sharks are crucial for the health of coral reef ecosystems. Algae grow on coral, which serve as food for herbivore fish, which are eaten by larger predatory fish. The latter are eaten by sharks. If sharks decline, less predatory fish are eaten and, consequently, more herbivorous fish are eaten. Thus, the algae thrive and compete with corals, which can lead to the death of such reefs (Rogers, 2016). This excess of algae blooms would suffocate the oceans as they suck the oxygen particles from sea water, leading to an ecological collapse (Breitburg et al., 2018). Another notorious consequence of shark decline is that many species would face extinction due to a disruption of the top-down food chain with a risk of desynchronizing the knots of life between the different species in terms of reproduction and consumption. As Rogers (2016) expounds:

Sharks often prey on the weak or ill members of marine life. These weak and ill members are easier to catch than strong, healthy members of a population. If the weak and ill members continue to thrive, it will weaken the larger population. First because they could potentially spread illness to the other members of the population, which could lead to massive die-offs. Secondly, because when these weaker members of the species are allowed to reproduce, it weakens the genetic makeup of the species as a whole, putting them at risk of extinction. (Rogers, 2016)

The disruption of such knots of life can, in turn, actively participate in aggravating global warming. With coastal ecosystems storing up to $50 \%$ of the world's carbon, if sharks decline, the synchronized livelihoods of the different species would be profoundly altered. Therefore, all these events would have tragic consequences for the world economy and especially those economically-poor areas that rely on their surroundings for food security and employment. In the case of the Maldives, shark conservation has been one of the most important factors to a) save an important part of their livelihoods and b) contribute to the fight against the transgression of the Planetary Boundaries and climate change with factual, tangible and direct action and policies. The Maldives have managed to arrest the Necrocene and keep some of the multispecies knots tied when it comes to sharks. Yet, this has proven to be insufficient in the long-run. 
With a strong tourism industry focused on scuba diving and marine life, and local fishing practices that solely depend on the wellbeing of their ecosystems, the massive decline of reef sharks would have been fatal for the Maldivians. In terms of tourism, if the biodiversity of attractions such as manta rays, whale sharks or reef sharks suffered a huge decline, the unmaking of knots of life and the solid TimeSpaces between the tourism industry, the Maldivian economy, the local communities, the health of their ecosystems and the subsequent catastrophe for fisheries would be fatal for an already threatened area. Nonetheless, tourism, as a fast-paced income source bound to the Necrocene logic has also become a causal factor in the environmental crisis that the Maldives are facing. The rapid growth in the housing industry and the 2009 law that allowed tourists to go on vacation to inhabited islands have exacerbated erosion and habitat degradation (Blomberg \& Blomvall, 2020). On the other hand, in terms of local fisheries, a decline of shark populations as an apex predator in an ecosystem can have critical consequences for the whole ecosystem's knots of life, both human and non-human. Although collaborating with the Necrocene, these activities that turn nature into commodities through labour are crucial for the livelihoods of the Maldivians. Therefore, a desynchronization of the knots of life that sustain such practices would undermine the livelihoods of the locals, especially for those living in peripheral areas.

With dangerous events such as the massive coral bleaching of 2016 that destroyed a big section of the northern Great Barrier Reef and affected the reefs in the Maldives (Slezak, 2016), global mass accumulation practices by the countries in the so-called global north and their globalized means of production are triggering the deathly nature of the Necrocene. This is affecting the ones that have, on the one hand, benefited the least from Capitalism and, on the other, dooming the areas that have contributed the least to the global necrosis and the trespassing of the Planetary Boundaries. To put it in a nutshell, it would be the transmutation of Capitalism, closing the loop of accumulation and extinction and, through these practices and for the first time in history, physically dooming a whole country.

As an area that is prone to natural disasters ${ }^{9}$, the transgression of the Planetary Boundaries will only worsen the Maldives' fate and the disruption of knots of life, gravely affected by coastal erosion, ocean acidification, rises in sea level, freshwater shortage and

${ }^{9}$ The Maldives are an active seismic area due to its closeness to the Sumatra Subduction Zone, where the 2004 Indian Ocean Tsunami originated. 
windstorms. Yet, although conservation efforts have been made, probably because they provide tourism fast-income to the country, the archipelago seems to be divided between the cities and the periphery. According to David et al. (2020), small islands such as Fuvahmulah have been affected by the maldevelopment of its coastal areas due to top-down policies that have leave aside the periphery, impairing the capacity of resilience. This resilience would, in turn, benefit from local knowledge and policies (David et al, 2020). Moreover, the Maldivian government is currently encouraging migration to the capital to reduce costs of service delivery, adopting the Safer Island Strategy project (Blomberg \& Blomvall, 2020). This project aims to consolidate the population onto fewer islands, reclaiming land in order to make it inhabitable (Speelman et al., 2017). However, as Stojanov et al. (2017) put it, the generation of artificial environments can have negative impact on the fragile Maldivian ecosystem, destroying reef ecosystems and jeopardizing the movement of other sediments that nourish the marine ecosystem. Furthermore, this project would only provide an immediate short term solution as, for instance, main cities like Mané are likely to be 30\% underwater by 2030 (Ahmed et al., 2020).

In the midst of different proposals on hard and soft coastal adaptation, together with the political instability of the last decade and a Decentralization Act from 2010 that does not seem to be working, local and regional communities have lost their power, being subjugated to the city vs. periphery dichotomy and the top-down politics implemented so far (Blomberg \& Blomvall, 2020). These approaches are just examples of the logic of the Necrocene and how even facing an unparalleled catastrophe, countries are unable to stop the capitalist motion as surplus value is prioritized over human and non-human lives. With a low level of trust in the central government, and top-down policies that do not consider either the local livelihoods from the peripheral noncentral islands or the ecological and sociopolitical diversity of such islands, tailored measures that include local participation are encouraged (Sovacool, 2012).

The Maldivians facing such calamity are being forced into a migration process that goes beyond ideology and politics at first sight, as it has been caused by non-human problems which will affect all the habitants of a specific coastal section alike in physical terms, regardless of their differences. They will become Climate Refugees. However, there are many inequalities in this crisis that are an inherent consequence of the capitalist logic, ideology and politics of life. The peripheral and financially-poor areas are demanding money from the central or wealthier states 
for the retreat process as resources are scarce. These demands are not being fulfilled by the Maldivian central government as they are only encouraging migration to central areas which will suffer the same fate in the next decades unless real local and global measures are implemented. In cultural terms, the Climate Refugees crisis can open up space for financial racism, dichotomizing Maldivian society between the "us" and the "other". Triggering the fear of the "other" through populist practices in order to alienate society while triggering neoliberal politics, the cultural realm of this crisis can be dangerous as it can deviate the focus from the real issue while creating a much more hostile sociopolitical situation for people that would have already lost their culture, heritage and land within the same archipelago.

The Maldives are the vivid example that the Necrocene and the Sixth Extinction go beyond non-human ecosystems. The Necrocene leads to cultural extinction, necro-realities and the untying of multispecies knots of life. With no proper environmental and sociopolitical policies, the Maldives will be gravely affected by the effects the Necrocene entails as many nonhuman ecosystems will perish and, consequently, many human cultures will suffer the deathly nature of the Necrocene, especially the ones on the peripheral areas.

\section{Beyond the Leviathan: Scanning the $X$}

With that being said, which are the ways out for the Maldives and, consequently, for the rest of the planet in the midst of the Necrocene? From a realistic perspective, the two most likely worldsystems that can arise in terms of eco-politics are what Wainwright \& Mann (2017) have coined as the "Climate Leviathan" and the "Climate Behemoth". Amongst these two future possibilities, Climate Leviathan seems to be the most likely to happen, but it is neither consolidated nor established. Climate Leviathan is "the dream of a planetary sovereign, (...) a regulatory authority armed with democratic legitimacy, binding technical authority on scientific issues and a panopticon-like capacity to monitor the vital granular elements of our emerging world: fresh water, carbon emissions, climate refugees and so on" (Wainwright \& Mann, 2017: 30). From a green Capitalism perception, this Leviathan would transcend the nation-state-based territorial container, becoming, with the inclusion of world-powers like China, Russia or India, a perpetuation of the role the northern liberal democratic states hegemony. Wainwright and Mann are wary of the possible cold-war-like political conflicts that this regime could cause between the world hegemonic powers. However, in such a bleak future, it is no surprise that most of the 
climate justice movement with an informed, rational perspective is pulling the theoretical grounds of ecology, conservation and neocolonialism towards a globalized planetary sovereign. On the other hand, we have Climate Behemoth, the most likely future if Capitalism and the world powers fail to understand and tackle climate change properly. If this happens, the world will devolve into populist factions, with nations rejecting international agreements in an everynation-for-itself manner to guard against climate impacts at home without rejecting massaccumulation practices, dooming the least wealthy (Wainwright \& Mann, 2017).

Either or, these two world-systems do not auger a prosperous future for the Maldives bearing in mind the current situation there. Even though a Climate Leviathan would push the Maldives to be "greener", it would only do so in order to perpetuate the business-as-usual logic and benefit the most powerful states in the world. This, in turn, would mean the decay of the peripheral islands unless they are transformed into money-making areas under the anvil of the practices of extractivism at the expense of an accepted destruction as long as it is sustainable for the Leviathan modus operandi. Conservation, ecology and sustainability seem to fall into a second place if the neoliberal superpowers are the only ones with the decision-making power. Thus, the Maldives need to aim for either a local policy that is powerful enough to fight the challenges at hand or a national environmental conservation that is not based on a top-down economically-centered approach so the periphery is not left aside.

On a planetary scale, neither of these two options tackles the core problem which is the capitalist logic. Considering the Climate Leviathan, green Capitalism led by the world's political and economic superpowers, and the neoliberal hegemony of the global north, should not be the eventual aim but a gateway towards a post-capitalist, democratic economy and egalitarian treatment of human and non-human ecosystems. Embracing the green capitalism alternative defended by most at the COP summits as the only hope is the acceptance that the battle is already lost. Furthermore, this alternative to a Climate Leviathan would be "beneficial" for the economically-rich but would doom those with less economic power. In other words, it would perpetuate a business-as-usual logic and its profound inequalities when one considers that Capitalism is adaptive; an entity that sucks everything at its reach so as to execute its psychopolitical and material deathly logic. If we are to find a way out of the Necrocene and the calamity it entails, one cannot blame neoliberalism per se, as some sort of psychological placebo 
that would allow us to perpetuate the capitalist logic in another shape. The problem was and is that Capitalism with its inegalitarian, discriminatory, competitive, top-down and colonialist logic has the power to infects everything within its reach. Only in a world that has transcended capitalist values as a mode of organization and in which sovereignty has become so fragmented and deformed that "the political can no longer be defined by the nation-state's sovereign exception" (Wainwright \& Mann, 2017: 173) can climate and, consequently, world justice be found.

Theorists, therefore, need to think beyond the logic of Capitalism and consider other alternatives for a future based on equity, solidarity and dignity for all human and non-human beings as utopian as this might appear in the short-run. Nonetheless, as Frankel (2018) postulates, "without new comprehensive socio-economic and environmental state roles to redefine socio-economic activity (Frankel, 2018: 285)", the possibility of a post-growth or postcapitalist equitable society is barely inexistent. Here, it is of paramount importance to engage with the vague idea of "Climate X" (Wainwright \& Mann, 2017). Although the concept still remains undertheorized, Climate X defines a world "that has defeated the emergent Climate Leviathan and its compulsion toward planetary sovereignty, while also transcending Capitalism" (Wainwright \& Mann, 2017). As an X in an equation, Climate X calls for radical alternatives that no longer attach themselves to the fallacies of green Keynesianism, green extractivism, the owning of the Earth or elite politics of adaptation, leaving aside the less-wealthy. Climate $\mathrm{X}$ is, therefore, based on solidarity, equity and dignity for all human and non-human beings, tearing apart the logic of the Law of Cheap Nature that has enslaved most of the living entities and ecosystems of the planet for centuries.

Fighting the Necrocene implies solving the $X$. This would not only mean a good theoretical start to palliate its effects, but also a liberating and emancipating reality for areas that are victims of neoliberal hegemony, such as the Maldives. Nevertheless, any attempt to commit to strong egalitarianism, quality of work and work justice, radical democracy, solidarity and dignity for all needs to have the transgression of Capitalism as a necessary condition because Capitalism systematically contradicts the realization of such goals and the consequent real utopia of a sociopolitical system based on egalitarian-democratic values. Thus, the Necrocene needs to be perceived from an ecological rationality perspective that allows us to overcome the 
individualistic neoliberal self-centered logic which has colonized, destroyed and ideologically hegemonized social, cultural and scientific spheres. This ideological hegemony has, in turn, created the uncanny paradox between a hyper-rational system that is in fact profoundly irrational without giving space to alternatives that might allow us to get rid of it. Yet, what is crucial is that the Environmental Humanities and Political Ecology thinkers embrace the debate from a constructive, ecological rationality that understands the different knots of life, and beyond-green complexion of the needs of this multifocal crisis. Although the Necrocene is catastrophist to the core, it allows theorists to bring to the center of the discussion both the deathly nature of Capitalism, and the urgent necessity of a radical alternative to the most likely futures that will perpetuate business-as-usual with a greener image, dooming the less-wealthy.

The Maldives will be critically affected in a short time by the dramatic repercussions of the transgression of the Planetary Boundaries and the consequent disruption of knots of life and TimeSpaces that made the area thrive in cultural, financial and ecological terms. The Necrocene and the transgression of the Planetary Boundaries will detrimentally affect the less-wealthy first and, as a consequence, the ones that have collaborated the least with the transgression of such boundaries. Green Capitalism is, therefore, a fallacy that would sustain the business-as-usual logic and its inequalities. Thus, the Necrocene needs to be fought back from a theory and action perspective that fleshes out the contemporary in an inclusive way. It might help us secularize the sociopolitical sphere from the religious-like and unquestionable Capitalist hegemonic ideology through theory, activism, solidarity and hope, acknowledging the real threat of a psychopolitical, necrotic, capitalist realism. None of us knows what the world will look like in the near future. Nonetheless, in order to confront the Necrocene, we need to solve the X, and we need to solve it together. 


\section{WORKS CITED}

AHMED, IFTEKHAR, KIM MAUND, THAYPARAN GAJENDRAN (2020). Disaster Resilience in South Asia: Tackling the Odds in the Sub-Continental Fringes. New York: Routledge.

ALKHARS, AYAH (2017). “Climate Refugees: Now Necessary for Island Nations to Find New Homes”. The Borgen Project. https://borgenproject.org/climate-refugees/ Accessed 22 September 2020.

BASTIAN, MICHELLE (2009). "Inventing Nature: Re-writing Time and Agency in a morethan-human World". Ecological Humanities, 47. http://australianhumanitiesreview.org/2009/11/01/inventing-nature-re-writing-time-andagency-in-a-more-than-human-world/ Accessed August 102020.

BASTIAN, MICHELLE (2017). "Encountering Leatherbacks in Multispecies Time Knots", In Deborah Bird Rose, Thom van Dooren and Matthew Chrulew's (eds.) Extinction Studies: Stories of Time, Death and Generations. New York: Columbia University Press: 149185.

BASTIAN, MICHELLE \& THOM VAN DOOREN (2017). "Editorial Preface. The New Immortals: Immortality and infinitude in the Anthropocene". Environmental Philosophy. 14 (1): 1-9. https://doi.org/10.5840/envirophil20171411

BATALLA, ORIOL. (2019). Planetary Catastrophism: Rethinking Hyperobjects, Extinction and Politics in the Necrocene Epoch. MA Thesis. Amsterdam: University of Amsterdam. https://scripties.uba.uva.nl/search?id=696352

BLOMBERG, CHARLOTTE \& SANDRA BLOMVALL (2020). A Comparison of Ecological, Social and Economic Sustainability in Adaptation Strategies in the Maldives and Kiribati. Dissertation. Malmö: Malmö University.

BOTKIN, DANIEL B. (2012). The Moon in the Nautilus Shell: Discordant Harmonies Reconsidered. Oxford: Oxford University Press.

BREITBURG, DENISE, MARILAURE GRÉGOIRE, KRISTEN ISENSEE, FRANCISCO CHÁVEZ, DANIEL CONLEY, VÉRONIQUE GARÇON, DENIS GILBERT, GIL JACINTO, LISA LEVIN, et al. (2018). "The Ocean is Losing its Breath: Declining Oxygen in the World's Ocean and Coastal Waters; Summary of Policy Makers". UNESCO \& IOC. https://doi.org/IOC/2018/TS/137REV

CLARK, JOHN P. (2019). Between Earth and Empire: From the Necrocene to the Beloved Community. Oakland: PM Press.

CRIST, EILEEN (2016). "On the Poverty of our Nomenclature”, In Jason W. Moore (ed.) Anthropocene or Capitalocene: Nature, History and the Crisis of Capitalism, Oakland: PM Press: 14-33. 
DAVID, GABRIEL C., ARNE HENNING, BEATE M. W. RATTER, VOLKER ROEBER, ZAHID, TORSTEN SCHLURMANN (2020). "Climate Change Induced Effects or Maldevelopment: Small Islands and Conflictive Attribution of Root Causes". EarthArxXiv. https://doi.org/10.31223/X5888P

FARBOTKO, CAROL \& HEATHER LAZRUS (2012). "The First Climate Refugees? Contesting Global Narratives of Climate Change in Tuvalu". Global Environmental Change, 22 (2): 382-390. http://dx.doi.org/10.1016/j.gloenvcha.2011.11.014

FRANKEL, BORIS (2018). Fictions of Sustainability: The Politics of Growth and PostCapitalist Futures. Melbourne: Greenmeadows.

GEISLER, CHARLES \& BEN CURRENS (2017). "Impediments to Inland Resettlement Under Conditions of Accelerated Sea Level Rise". Land Use Policy, 66: 322-330.

GUATTARI, FÉLIX (2000). The Three Ecologies. First published in 1989. Translated by Ian Pundar and Paul Sutton. London/New Brunswick: The Athlone Press.

HARAWAY, DONNA (2015). "Anthropocene, Capitalocene, Plantationocene, Chthulucene: Making Kin”. Environmental Humanities. 6: 159-165.

KELMAN, ILAN, JUSTYNA ORLOWSKA, HIMANI UPADHYAY, ROBERT STOJANOV, CHRISTIAN WEBERSIK, ANDREA C. SIMONELLI, DAVID PROCHÁZKA \& DANIEL NĚMEK (2019). "Does Climate Change Influence People's Migration Decisions in the Maldives?". Climatic Change, 153: 285-299. https://doi.org/10.1007/s10584-019-02376-y

MBEMBE, ACHILLE (2003). "Necropolitics". (Libby Meintjes Trans.). Public Culture, 15(1): 11-40.

McKIBBEN, BILL. (1989). The End of Nature. New York: Random House.

McBRIEN, JUSTIN (2016). "Accumulating Extinction: Planetary Catastrophism in the Necrocene”, In Jason W. Moore's (ed.) Anthropocene or Capitalocene?: Nature, History and the Crisis of Capitalism, Oakland: PM Press: 116-137.

MEEHL, GERALD A., THOMAS STOCKER, WILLIAM D. COLLINS, PIERRE FRIEDLINGSTEIN, AMADOU GAYE, JONATHAN GREGORY, AKIO KITOH, RETO KNUTTI, JAMES MURPHY, AKIRA NODA, SARAH RAPER et al. (2007). "Global Climate Projections", In IPCC WG1 Fourth Assessment Report. https://www.researchgate.net/publication/216812920_Global_Climate_Projections

Accessed 22 September 2020.

MERONE, LEA \& PETER TAIT (2018). "Preventing Disaster in the Pacific Islands: The Battle Against Climate Disruption". Australian and New Zealand Journal of Public Health, 42 (5): 419-420. https://doi.org/10.1111/1753-6405.12823

MOORE, JASON W. (ed.) (2016). Anthropocene or Capitalocene?: Nature, History and the Crisis of Capitalism. Oakland: PM Press. 
MORTON, TIMOTHY (2016). Dark Ecology: For a Logic of Future Coexistence. New York: Columbia University Press.

NURSE, LEONARD, ROGER McLEAN, JOHN AGARD, LINO BRIGUGLIO, VIRGINE DUVAT, NETATUA PELESIKOTI \& EMMA TOMPKINS (2014). "Chapter 29: Small Islands", In Climate Change 2014: Impacts, Adaptation and Vulnerability. Part B: Regional Aspects. Fifth Assessment Report of the IPCC.

PILKEY, ORRIN H., LINDA PILKEY-JARVIS \& KEITH C. PILKEY (2016). Retreat from a Rising Sea: Hard Choices in an Age of Climate Change. New York: Columbia University Press.

PLUMWOOD, VAL (2002). Environmental Culture: The Ecological Crisis of Reason. London/New York: Routledge.

PURDY, JEDEDIAH (2010). After Nature: A Politics for the Anthropocene. Cambrdige: Harvard University Press.

ROCKSTRÖM, JOHAN, WILL STEFFEN, KEVIN NOONE, ASA PERSSON, STUART III CHAPIN, ERIC LAMBIN, TIMOTHY M. LENTON et al. (2009). "Planetary Boundaries: Exploring the Safe Operating Space for Humanity". Ecology and Society. 14 (2): 32. https://doi.org/10.5751/ES-03180-140232

ROGERS, MICHAEL (2016). "What if Sharks Disappeared?". Shark Sider. https://www.sharksider.com/every-shark-disappeared\%E2\%80\%A8/ Accessed 15 September 2020.

ROSE, DEBORAH BIRD (2012). "Multispecies Knots of Ethical Time." Environmental Philosophy. 9 (1): 127-140. DOI: 10.5840/envirophil2012918.

SLEZAK, ROBERT (2016). "Coral Bleaching Spreads to Maldives, Devastating Spectacular Reefs". The Guardian. https:/www.theguardian.com/environment/2016/jun/01/coralbleaching-spreads-to-maldives-devastating-spectacular-reefs Accessed 15 August 2020.

SOVACOOL, BENJAMIN K. (2012. "Perceptions of Climate Change Risks and Resilient Island Planning in the Maldives". Mitigation and Adaptation Strategies for Global Change. 17: 731-752.

SPEELMAN, LAURENS H., ROBERT J. NICHOLLS \& JAMES DYKE (2017). "Contemporary Migration Intentions in the Maldives: The role of Environmental and other factors". Sustainability Science. 12: 433-451.

STIEGLER, BERNARD (2018). The Neganthropocene. (Daniel Ross Trans.). London: Open Humanities Press.

STOJANOV, ROBERT, ILAN KELMAN, DAVID PROCHÁZKA, DANIEL NĚMEK \& BARBARA DUŽÍ (2017). "Climate Change and Migration in the Maldives". Georgetown Journal of International Affairs. https://www.georgetownjournalofinternationalaffairs.org/onlineedition/2017/8/16/climate-change-and-migration-in-maldives Accessed 20 August 2020. 
TASOFF, HARRISON (2020). "Reef Sharks in Decline". UCSB: The Current. https://www.news.ucsb.edu/2020/019975/reef-shark-roundup. Accessed 18 September 2020.

TITUS, JAMES G. (1989). "Policy Implications of Sea Level Rise: The Case of the Maldives". Rising Sea. http://papers.risingsea.net/Maldives/Small Island States 3.html Accessed 03 March 2021.

TOMBA, MASSIMILIANO (2009). "Historical Temporalities of Capital: An Anti-Historicist Perspective". $\quad$ Historical $\quad$ Materialism. $17 \quad$ (4): https://doi.org/10.1163/146544609X12537556703115

UNZONDU, CHAKA (2013). "Theorizing Necro-ontologies, Resisting Necro-economics". Atlantic Studies: Global Currents, $10 \quad$ (3), 323-349. https://doi.org/10.1080/14788810.2013.809918

WAINWRIGHT, JOEL \& GEOFF MANN (2017). Climate Leviathan: A Political Theory of our Planetary Future. London / New York: Verso Books.

ORIOL BATALla is a researcher in the fields of the Environmental Humanities, Critical Theory and Political Ecology and MA in Comparative Literature and Cultural Analysis for the University of Amsterdam. His latest research and publications are focused on the concepts of Anthropocene and Necrocene, Non-Human and beyond-life-and-death agents, and alternatives to Capitalism. He is actively looking for a $\mathrm{PhD}$ position regarding such topics. 